\title{
RESPONSES
}

\section{What is Natural About Witchcraft?}

\author{
Miriam Adeney
}

Traditional classic anthropologists-such as E.E. Evans Pritchard, S.F. Nadel, Clyde Kluckhohn, and Claude Levi-Strauss-have been agnostic about the existence of the supernatural, at least in so far as it might affect research. Still, they have recognized that people in many societies do believe in witchcraft. How have they explained this? In particular, what are the natural stimuli to a belief in witchcraft? This short reflection will reference some ethnographies which may provide a little historical background for the extensive research reported in the paper under discussion. ${ }^{1}$

\section{Functions and Fault Lines}

It has been hypothesized that witchcraft and sorcery perform some needed functions in many societies, and because they are functional they are believable for the people in the cultures where they appear. They may function, for example, as an arm of law and politics, as a stimulus to economic distribution, as a cause for rupturing social relations which have become too cramping, or as a socially tolerable outlet for aggression, anxiety, or emotional purging and display. Witchcraft and sorcery are often intimately integrated into a culture, upholding and in turn receiving support from most of the other major institutions in the culture. As well, witchcraft and sorcery can be functional for individual members of society by providing opportunities for aggression, wealth, power, vengeance, prestige, attention, or psycho-sexual satisfaction (Adeney 1974).

Furthermore, in any given society some structured relationships will be more likely than others to breed tensions. It is along the fault lines of these relationships that aggressions will tend to flare out. Who bewitches whom may correlate with these structural tensions.

For example, among the Nupe of Africa witchcraft accusations traditionally have zoomed from men to women. Nupe marriages have tended to be stressful. Wives often are in higher economic brackets than their husbands because women are the itinerant traders. Wives pay for children's education, son's bride-prices, and family feasts. Husbands who need cash may have to borrow from their wives. Yet the Nupe ideal is that the husband will command and control. Bewildered and plagued by low self-esteem, men project evil intentions and powers onto the women who wield decisive power in the actual world (Nadel 1960). By contrast, Dobu people in the south Pacific experience slightly different marriage stresses, and witchcraft accusations flow both ways between husband and wives (Fortune 1964).

Among the Mesakin and Korongo of Africa all the witches are men, and accusations simmer between impatient nephews and the uncles who must pass down their inheritance in these matrilineal and age-graded societies (Nadel 1960). Among the Nyakyusa of Tanzania, witch accusations fly between neighboring wives, whereas among the Pondo of South Africa they sizzle between mothers-in-law and daughters-in-law (Wilson 1951). Again these reflect certain social strains specific to these societies. In Cebu in the Philippines, rural witchcraft/sorcery erupts over land rights, but in the urban environment it is prompted by alienation of affection (Lieban 1967).

Cultures and societies give a shape to witchcraft. Wherever it flourishes, Christian leaders should ask: What are the possible functions of witchcraft here? What outlets is it providing? What needs is it meeting? What channels does the society provide for expressing hostility and aggression, for stimulating economic redistribution, for ensuring justice, and for rupturing social relations which have become too cramping? How do people channel their diffuse anxiety? How do they experience deep cathartic emotional purging?

And what are the lines of tension in the local social structure? For example, the report by Priest, Ngolo and Stabell (2020) identifies the step-parent/step-child relationship as a fault line that may contribute to witchcraft accusations, resulting in "story after story of

\footnotetext{
'These comments draw from classic anthropological studies which I researched during my graduate school studies, yielding a publication "What Is "Natural" About Witchcraft and Sorcery" Missiology: An International Review, July 1974. Although dated, these ethnographies yield many intriguing details and theoretical frameworks.
} 
the rather straightforward human dynamics discovered to lie behind allegations" (34).

\section{Caveats and Elaborations}

Regarding the excellent research in this report, three minor points and one major point will be explored. First, the report asserts that "whenever misfortune strikes, major efforts are exerted to identify the evil witch causing the problem, with special techniques and powers . . ." (44). Yet this may not be the case everywhere. Clyde Kluckhohn asserted that Navaho, who value intense interdependence but who can grate on one another when confined together in their winter hogans, find outlets for expressing anger by accusing witches who are unnamed and "far away." True, occasionally persons known and close at hand are accused. Then killing may result. But most accusations are against vague, distant witches. This allows Navaho an outlet for releasing stress while continuing to live together in harmony in close quarters $(1944,89)$.

A second caveat concerns several trainers' view that persons do not harm others supernaturally. Interestingly, rather than fighting the view that humans can harm others mysteriously, Dr. Daniel Fountain built on it. Fountain successfully ran a major hospital in Congo from 1961 to 1996. In his public health campaigns, he taught, "If you know you should use a toilet, but you use a field, then you are purposely exposing your neighbors to harm, just as if you were doing sorcery against them. Similarly, if you avoid immunizations, you are exposing your neighbors to harm, just like a sorcerer" (2014).

A third point is a suggested addition. Asking "Where do we go from here?" the report begins with New Hybridities (40), referring to healthy contextualizations. It commends careful attention to (1) local Christian patterns, to (2) general cultural patterns in the local society, and to (3) Scripture. Besides these, anthropologist Jacob Loewen has suggested (4) reflecting on positive practices of churches throughout the world. He employed this in a Latin American tribe, where they explored alternatives in child education, prayer meeting styles, and communion resources. A range of illustrations stimulated local Christian imaginations (Loewen 1964, 246-7).

\section{Worldview Reorientation}

Structural anthropologists argue that witch beliefs give people handles for coping with stressful threats. Bronislaw Malinowski, for example, says such beliefs help people move from an inability to control their destiny to "manageable malice" $(1945,95)$.

Malice, aggression, abnormality, anxiety, and tension are part of life, worked through in different ways in different cultures. For Christians, however, battle should not be the preeminent focus for dealing with evil. This is my fourth reflective point. Mennonite anthropologist Paul Hiebert has asserted:

*The central issue is not power but holy and loving relationships.

*The way to victory is not primarily battle but the cross followed by resurrection.

* Satan is not independent and he never wins

* Human beings are responsible, not pawns of higher forces. (Hiebert 1994, 203-215)

In every society these truths will call for a radical reorienting of our worldview. Westerners may need this most, because we have been raised with a bias toward battle. Commenting further, Hiebert provided background:

Central to the IndoEuropean worldview was the myth of a cosmic spiritual battle between good and evil ... In IndoEuropean battles, the good characters become like their enemies. They end up using violence, entering without warrants, lying, committing adultery, and killing without due process. All of this is justified in the name of victory. Righteousness and love can be established only after the victory is won, and are second in importance...

Relationships in the cosmos are based on competition ... Battle is the center of the story. When the battle is over, the story is done. The final words are "and they won (or were married, or beat out a rival) and lived happily ever after." But there is no story worth telling about the "happily ever after." The adventure and thrill is in the battle, and to that we return again and again (ibid).

If this is our heritage, it is not surprising that belligerent attitudes seep into our daily life. Without our noticing, love and peace may be marginalized. While Congolese societies do not emphasize an IndoEuropean worldview, they do seem to emphasize a battle between evil and God. Here is where the training workshops and ongoing pastoral counseling of the EPED are so valuable. Here pastors learn more accurate translations of biblical terms, and more appropriate interpretations of biblical teaching-for example, that the demon-possessed whom Jesus delivered were victims similar to sick people. Here pastors rediscover the extensive biblical emphasis on care for the vulnerable, including children. Some of these pastors undergo dramatic paradigm shifts. Instead of forcing confessions from children, they now seek to nurture children and help their accusers deal with the social, economic, and psychological stresses that plague them. 


\section{References}

Adeney, Miriam. 1974. What Is Natural About Witchcraft and Sorcery? Missiology: An International Review 2(3) 377-395.

Evan-Pritchard, E.E. 1935. Witchcraft. Africa 8:420.

Fortune, R.F. 1954. Sorcerers of Dobu. New York: Harper and Brothers.

Fountain, Daniel. 2014. Health for All: The Vanga Story. Pasadena CA: William Carey Library.

Hiebert, Paul. 1994. Biblical Perspectives on Spiritual Warfare. In Anthropological Reflections on Missiological Issues. Grand Rapids MI: Baker Books.

Kluckhohn, Clyde. 1944. Navaho Witchcraft. Boston: Beason Press.

Levi-Strausss, Claude. 1963. Structural Anthropology. New York: Basic Books.

Loewen, Jacob. 1964. The Church: Indigenous and Ecumenical. Practical Anthropology 11:241-258.

Malinowski, Bronislaw. 1945. Reflections on Witchcraft. In The Dynamics of Culture Change. New Haven CT: Yale University Press.

Nadel, S.F. 1935. Witchcraft and Anti-Witchcraft in Nupe Society. Africa 8:444-448.

Nadel, S.F. 1960. Witchcraft in Four African Societies: An Essay in Comparison. In Cultures and Societies of Africa. Simon and Phoebe Ottenburg, eds. New York: Random House.

Priest, Robert J., Abel Ngolo and Timothy Stabell. 2020. Christian Pastors and Alleged Child Witches in Kinshasa, DRC. On Knowing Humanity Journal 4(1):1-51.

Wilson, Monica. 1951. Witch Beliefs and Social Structure. American Journal of Sociology 56: 307-313.

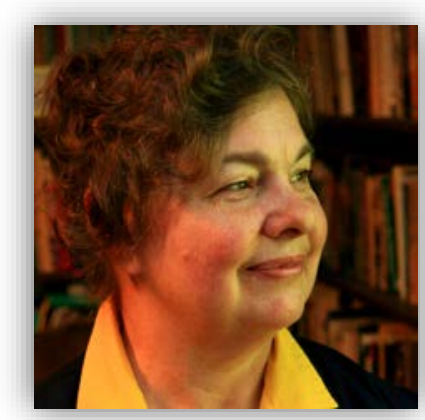

Miriam Adeney (B.A Wheaton College, M.A. Syracuse University, Ph.D. Washington State University) is an anthropologist/missiologist and professor at Seattle Pacific University. From that base she works on six continents. Miriam has been President of the American Society of Missiology and has received Lifetime Achievement Awards from the Christians for Biblical Equality and from Media Associates International. She is an author and trainer of nonwestern Christian authors. Her books include Kingdom Without Borders: The Untold Story of Global Christianity; Daughters of Islam: Building Bridges with Muslim Women: God's Foreign Policy: Practical Ways to Help the World's Poor; and several others. She is married, the mother of three sons, and a member of University Presbyterian Church. 